\title{
SYSTEMATIZATION OF SCIENTIFIC APPROACHES TO THE INTERPRETATION OF INFORMATION ECONOMY
}

\author{
Nataliya Kholiavko' \\ Chernihiv National University of Technology, Ukraine
}

\begin{abstract}
The purpose of the article is to analyse and systematize scientific approaches to the interpretation of the essence of the information economy. The research object: scientific approaches to the interpretation of the essence of the concept of "information economy". The theoretical and methodological base of the research consists of works by D. Bell, Z. Brzezinski, J. Baudrillard, M. Castells, Yoneji Masuda, F. Machlup, M. Porat, A. Toffler, which are devoted to issues of development of information society. Analysis of recent research and publications allows noting an increasing scientific interest in issues of formation of the economy of information type. The essence and features of information economy are considered in scientific papers of scholars such as Hrynkevych S., Iliash A., Krystynevych S., Malyk I., Nikolaiev Ye., Bazhal Yu., Tolstiakov R., Shkarlet S., Fedulova L., Chukhno A., and others. Research methods: analysis, content analysis, synthesis, system method. Increasing scientific interest in the formation of the information economy leads to an increase in the number of publications on this topic; pluralism of scientific approaches to the consideration of the essence of the information economy actualizes the need for their systematization. The theory of information economy logically follows and is a component of the theory of the development of information society. Along with it, there is an approach in the scientific literature, according to which scholars identify the concept of information society and information economy. In our opinion, this approach is not well-balanced, since the term "information society" is inherently wider than "information economy". The latter can be considered as an inherent component of the information society, which development is determined by a number of specific factors. In other words, these terms are closely interrelated and they should be investigated in the context of links between them, however, we should not consider them as synonymous terms. There is no the only consistent interpretation of the term "information economy" in the scientific literature, which is explained by differences in views and research methods of different scholars. Moreover, this is complemented by the high dynamism of the economic component of the information society, which is why new aspects of its study are constantly emerging. Conclusions. The article analyses views of domestic and foreign scholars on the essence of the information economy. Systematization of scientific approaches made it possible to note that their pluralism is determined by differences in the views of scientists, the methodology used, scientific schools, etc. The analysed definitions are characterized by different degrees of concreteness, abstractness, scale, complexity, completeness, and systematicity in disclosing the essence of information economy with possible identification of the component composition and determinants of its development. Based on the systematization of scientific approaches to the interpretation of this concept, it is proposed to consider the information economy as a type of economic system, which is characterized by the defining role of information and information technologies in the processes of production, exchange, distribution, and consumption, as well as in the development of basic industries and the national economy as a whole. The author emphasizes that ensuring the competitiveness of economic entities at the micro (local, sectoral), macro (national), and mega (international) levels requires the implementation of flexible and highly adaptive mechanisms for generation, accumulation, processing, analysis, information transfer, effective distribution and use of information resources, rapid update and implementation of innovative information and communication technologies. In terms of formation of the information economy, industries, sectors, and spheres, which are capable of producing knowledge and information, in the first place - higher education, science, play a particular role. Prospects for further research are the study, structuring, and systematization of scientific approaches to the correlation of the categories "information economy" and "knowledge economy" with the specification of their key features and specific characteristics. This will make it possible to substantially deepen the theoretical and methodological foundations of research into the formation and development of an economy of an informational type.
\end{abstract}

Key words: information economy, knowledge economy, information, information resources, information and communication technologies.

JEL Classification: A10, B00, E00, N00, O10, O3, Y30, Y40

\footnotetext{
Corresponding author:

${ }^{1}$ Department of Theoretical and Applied Economics, Chernihiv National University of Technology.

E-mail: natasha290186@ukr.net
} 


\section{Introduction}

Socio-economic development of the leading countries of the world takes place in a number of challenges, the key among which one can determine: the high dynamics of the exogenous and endogenous environment; the variability of factors and the specifics of their impact on the national economy; rapid informatisation, automation, robotisation of production processes; an increase in the knowledge content of the complexity of production; penetration of information and communication technologies in various spheres of society life, including in economic relations. These challenges lead to the transformation of the national economic system, its transition to the informational type. Economists-practitioners and scholars note the intensification of processes of formation of the information economy. The development of effective mechanisms and strategic approaches to effective state regulation of the national economy in terms of its transition to functioning on the basis of informational means the expediency of conducting previous thorough scientific research, the formation of the theoretical and methodological basis for the implementation of relevant processes.

World trends of economic development confirm the thesis of the significant transformative influence of information and modern technologies on the course of economic processes. Increasing access to information resources and increasing the speed of obtaining information leads to a change in the economic behaviour of actors in making decisions: customers (consumer choice), commodity producers (when defining answers to fundamental economic problems), suppliers (when choosing a logistics strategy), etc. Information technology intensifies production processes, shortens the life cycle of goods. Changes in the structure of factors of production, productive forces, factors of competitiveness of economic entities under the influence of information, the formation of the market for information services - all this justifies the need for scientific research, the study of the theoretical foundations of the functioning of the economy of information type.

The theory of information economics flows logically and is a component of the theory of information society development (Hrynkevych, 2015; Krystynevych, 2008). Along with this, there is an approach, in the scientific literature, by which scientists identify the concept of the information society and the information economy. In our opinion, such an approach is not sufficiently balanced, since the term "information society" in its essence is wider than the "information economy". The latter can be considered as an inherent component of the information society, which development is determined by a number of specific factors. In other words, these terms are closely interrelated and they should be investigated in the context of links between them, however, we should not consider them as synonymous terms.

There is no the only consistent interpretation of the term "information economy" in the scientific literature, which is explained by differences in views and research methods of different scholars. Moreover, this is complemented by the high dynamism of the economic component of the information society, which is why new aspects of its study are constantly emerging.

\section{Views of foreign scholars on the essence of the information economy}

In scientific terms, the concept of information economy was introduced by Mark Porat, an American economist at the Stanford Center for Interdisciplinary Research. In his work of the same name, the scientist, having analysed the information-intensive activities and their contribution to the formation of the GNP of the United States of America, comes to the conclusion about the formation of an information economy. M. Porat, characterizing the informational economy, proposed to divide it into the primary and secondary information sectors. In general, the scholar associates the development of the information society with the expansion of the information sector of the economy (Mark U. Porat, 1977).

F. Machlup follows similar views on the essential aspects of the information economy. In particular, this concept is interpreted as a type of economy, in which activities for the production, processing, storage, and transfer of knowledge and information form the overwhelming share of GDP of the country (Machlup, 1962). By sharing this view on the category under study, along with this, we consider it expedient to note its broad, generalized character, which determines the appropriateness of its concretization.

According to M. Castells, theinformation economy can be defined as the economy, the competitiveness of which subjects depends on their "ability to generate, process, and effectively use knowledge-based information" (Castells, 1996-1998). The scholar emphasizes the fact that information technologies make a special impact on economic processes. The current trends in scientific and technological and innovative development are demonstrating the increasing influence of dynamically updated information and communication technologies on the economy, which in practice confirms the abovementioned thesis formulated by M. Castells.

Nizhegorodtsev R.M. proposes the interpretation of the information economy, a broad enough in its internal content. In the monograph "Information Economics", the scientist points out the following definition: "this is an economic sector that studies economic changes that operate in the field of production and reproduction of scientific and technological information, scientific 
knowledge" (Nizhegorodtsev, 2002). According to the scholar, the subject of the information economy covers economic processes and economic laws, according to which the processes of production, exchange, distribution, and consumption of scientific and technical information are carried out (Nizhegorodtsev, 2002). Analysis of the above demonstrates, firstly, the expediency of expanding the subject - with the inclusion of all types of information (that is, without limitation, only the scientific and technical information). Secondly, the scholar's position regarding the economic laws included in the research subject requires a specification (Nikolaiev, 2010).

In the thesis, Tolstyakov R.R. interprets the informational economy as "a part of the post-industrial economy, which is determined by the progress of science and technology, which makes high technology the basis of technical and economic development" (Tolstyakov, 2003). The critical analysis of the above definition allows marking its concentration on aspects of factor support for the formation of the information economy. The latter is explained by the subject of research in the thesis of Tolstyakov R.R.

B.V. Korneychuk outlines two aspects of the consideration of the information economy: 1) as a modern stage of development of civilization, the defining feature of which is the prevalence of creative work; 2) as "the economic theory of information society” (Korneychuk B., 2006). We consider this approach justified, taking into account the complexity and high dynamics of the information economy as a research object.

According to Rakitov A.I., that economy can be called as information, in which "the cost of information search goes to zero" (Rakitov, 1998). We unequivocally agree on the crucial importance of information and ensuring wide access to information resources of all interested economic entities. However, given this, the formulated by A.I. Rakitov definition seems to us somewhat limited since it does not fully reflect processes of generation, production, analytical processing, and transfer of information, knowledge, information technology.

S. Diatlov considers the information economy from the point of view of the systematic approach. To the subject of study of the specified type of economy, scientists are assigned: economic relations concerning the production, exchange, accumulation, and consumption of information; laws of self-organization of economic systems; aspects of rational search and use of information resources; systematic organization of economic processes and phenomena in the perspective of informatisation (Diatlov, 1998). Fully sharing the idea of the need for a systematic approach to the interpretation of the essence of the information economy, yet we have to note the excessive breadth of the subject of the research object, which greatly complicates and aggravates the process of its study. And accordingly, in our opinion, it needs to be optimally narrowed in order to provide more specificity and purposefulness of the research.

Analysing the experience of foreign scientists in the problem of interpreting the essence of the information economy, we consider the position of Gubaidullina D.M. as appropriate, who examine this concept as "the stage of development of human society, the totality of all relations arising between economic entities on the basis of production, distribution, change, and consumption information" (Gubaidullina, 2011). This definition combines two the most widely used scientific approaches. Moreover, Gubaidullina D.M. defines the informational economy as a factor in promoting the development of a new information technology (Gubaidullina, 2011).

\section{Views of Ukrainian scholars on the essence of the information economy}

Ukrainian scholars have fundamental developments in the study of issues of the formation of the information economy. In particular, Yu.M. Bazhal in this regard emphasizes "the use of knowledgeable information for the production of a new product, competitive in the world market, not necessarily informational, but such that, having mass sales, provides economic wealth and development of producer countries" (Bazhal, 2006). In the monograph "Ukraine in the Measurement of the Knowledge Economy" edited by academician V.M. Heiets, it is proposed to consider the economy as "knowledge economy that involves the use of knowledge for economic development" (Bazhal, 2006; Chala, 2012). In this monograph, scholars are able to withdraw from the consideration of the information economy solely through the prism of aspects of the analysis of information resources and technologies, expanding the research problem to issues of knowledge generation and cost-effective implementation of information technologies.

The authors of the monograph "Priorities of National Economic Development in the Context of Globalization Challenges" call the information economy "a special type of economy, in which information is a decisive productive resource, based on information production and information technologies" (Heiets, Mazaraki, 2008). One recognizes the equation of the information economy to the knowledge economy on the internal content of both concepts as quite acceptable.

A thorough approach to the interpretation of the essence of the information economy is proposed by S. Shkarlet and M. Dubyna, considering this term as "the type of economic system, within which information plays a key role in the development of the main spheres and industries of national production, is an integral part of the implementation of processes of production, distribution, exchange and consumption, 
further development of such a system is directly related to the creation and implementation of new information technologies in the activities of various economic entities" (Shkarlet, Dubyna, 2017). In a joint paper, scholars focus on transforming the essence and structure of economic processes under the influence of innovative information technologies, as well as changing the working process (collection, storage, processing, transfer, use) with economic information itself (Shkarlet, Dubyna, 2017).

Domestic scholar A.O. Maslov devotes a series of his scientific works to the study of scientific and methodological principles of functioning of the information economy in Ukraine and the world. On the basis of conducted researches and thorough study of scientific achievements of foreign scientists, Maslov A.O. proposes to consider the information economy as "an economy that was formed in combination and covers elements of the traditional, network, and knowledge economy, and created its own special content elements based on information and knowledge" (Maslov, 2012). From this definition, it is clear that the scholar manages to combine various scientific approaches, as well as to define clearly the relationship between the concepts of information and knowledge economy (among them, including the elements of the latter in the structure of information economy along with the components that characterize the traditional and network economy). In addition, Maslov A.O. in his publications specifies features and specific structural elements inherent in the information economy itself at the stage of its formation. According to V.L. Pleskach and T.H. Zatonatska, the informational economy covers "electronic economic activity, where business activities in the field of information services, their production and exchange, where information and knowledge are the main resources, prevail" (Pleskach, Zatonatska, 2007). We believe that in the context of modern realities regarding the growth of the value and influence of information and communication technologies on economic processes, the above definition should be supplemented with aspects that reflect the specifics of such an influence with the identification of directions of transformation of economic relations in the conditions of informatisation of the national economy and society.

Melnychuk $\mathrm{O}$. adheres to the position that is close to this approach, interpreting the informational economy as "an innovative type of economic activity, where the main resources are the information and knowledge that ensure the functioning of e-business and the provision of electronic services by the state in terms of minimization of information search costs" (Melnychuk, 2014). We can note some limitation of this definition by isolating and summarizing the essence of the analysed concept to one structural element - e-commerce, which we consider to be unjustified even in view of the high dynamism and perspective of this element.

Chala O.V. states that the information economy "includes the creation and use of information resources in a structured information space, and also provides

Table 1

Interpretation of the essence of the information economy in dictionaries

\begin{tabular}{|c|c|c|}
\hline Definition & Source & Reference to the source \\
\hline $\begin{array}{l}\text { Information economy - "an economy in which } \\
\text { knowledge, information, and services are more valuable } \\
\text { than manufacturing; the technological revolution } \\
\text { associated with the computer and the information } \\
\text { economy has accelerated the shift of industrialized } \\
\text { countries from manufacturing-based economies toward } \\
\text { service-based economies" }\end{array}$ & $\begin{array}{c}\text { Cambridge Business English Dictionary, } \\
\text { Cambridge University Press }\end{array}$ & $\begin{array}{l}\text { http://dictionary.cambridge.org/ } \\
\text { dictionary/english/information- } \\
\text { economy }\end{array}$ \\
\hline $\begin{array}{l}\text { Information economy - "an economy based on } \\
\text { the effective acquisition, dissemination, and use of } \\
\text { information, rather than on the means of production" }\end{array}$ & Oxford Dictionary & $\begin{array}{l}\text { https://en.oxforddictionaries.com/ } \\
\text { definition/information_economy }\end{array}$ \\
\hline $\begin{array}{l}\text { Information economy - "an economy in which data and } \\
\text { intellectual work are a more important source of wealth } \\
\text { than manufacturing" }\end{array}$ & Macmillan Dictionary & $\begin{array}{l}\text { http://www.macmillandictionary. } \\
\text { com/dictionary/british/information- } \\
\text { economy }\end{array}$ \\
\hline $\begin{array}{l}\text { Information economy - "a type of modern economy, } \\
\text { in which the dissemination of information technology } \\
\text { in the field of material and non-material production, } \\
\text { the transformation of information to one of the most } \\
\text { important factors of socio-economic progress of society } \\
\text { and person are taking place" }\end{array}$ & $\begin{array}{c}\text { Economic Glossary (Економічний } \\
\text { словник-АовіАник) }\end{array}$ & $\begin{array}{c}\text { http://subject.com.ua/economic/ } \\
\text { dict/363.html }\end{array}$ \\
\hline $\begin{array}{l}\text { Information economy - "an economy, in which most of } \\
\text { the gross domestic product is provided with activities in } \\
\text { the production, processing, storage, and distribution of } \\
\text { information and knowledge, with more than half of the } \\
\text { employees involved in this activity" }\end{array}$ & $\begin{array}{c}\text { Financial Dictionary (Финансовый } \\
\text { словарь) }\end{array}$ & $\begin{array}{l}\text { https://dic.academic.ru/dic.nsf/ } \\
\text { fin_enc } / 23440\end{array}$ \\
\hline
\end{tabular}


opportunities for the production of intellectual capital and innovation and thus affects economic processes and socio-economic relations" (Chala, 2012). On the one hand, this definition is sufficiently complex and broad in its content; however, on the other hand, it deprives it of specifics and does not reflect the specificity of the term.

Ye.B. Nikolaiev rightly notes possibility to consider the essence of the information economy in the broad and narrow sense, respectively, as:

- "economic system where the industries, in which the intellectual product is created, occupy a central place and have a decisive influence on the operation of all other industries" (Nikolaiev Ye., 2010);

- "a separate sector of the national economy, where an intellectual product (science, education, etc.) is created" (Nikolaiev, 2010).

To ensure the completeness and comprehensiveness of the analysis of approaches to the interpretation of the essence of the information economy, Table. 1 presents a definition of some dictionaries. The definitions given in the table fully correspond to the basic scientific views. In domestic and foreign dictionaries, the emphasis is made on the exceptional role of information and the powerful transformational impact of information technology on economic relations and the state of the national economy as a whole.

\section{Scientific approaches to the definition of the subject of the information economy}

Thus, the elaboration of scientific sources allows us to conclude that there is no single agreed approach to the interpretation of the essence of the information economy. By systematizing the definitions formulated by foreign and Ukrainian scholars, we can note that pluralism is determined by differences in the views of scholars, applied methodology, scientific schools, etc. The analysed definitions are characterized by different levels of concretization, abstraction, scale, complexity, completeness, and systematicity in disclosing the essence of the information economy, including the possibility of identifying the component composition and determinants of its development. There diversified scientific views on this term are generalized and the subject of the study is presented schematically in Fig. 1.

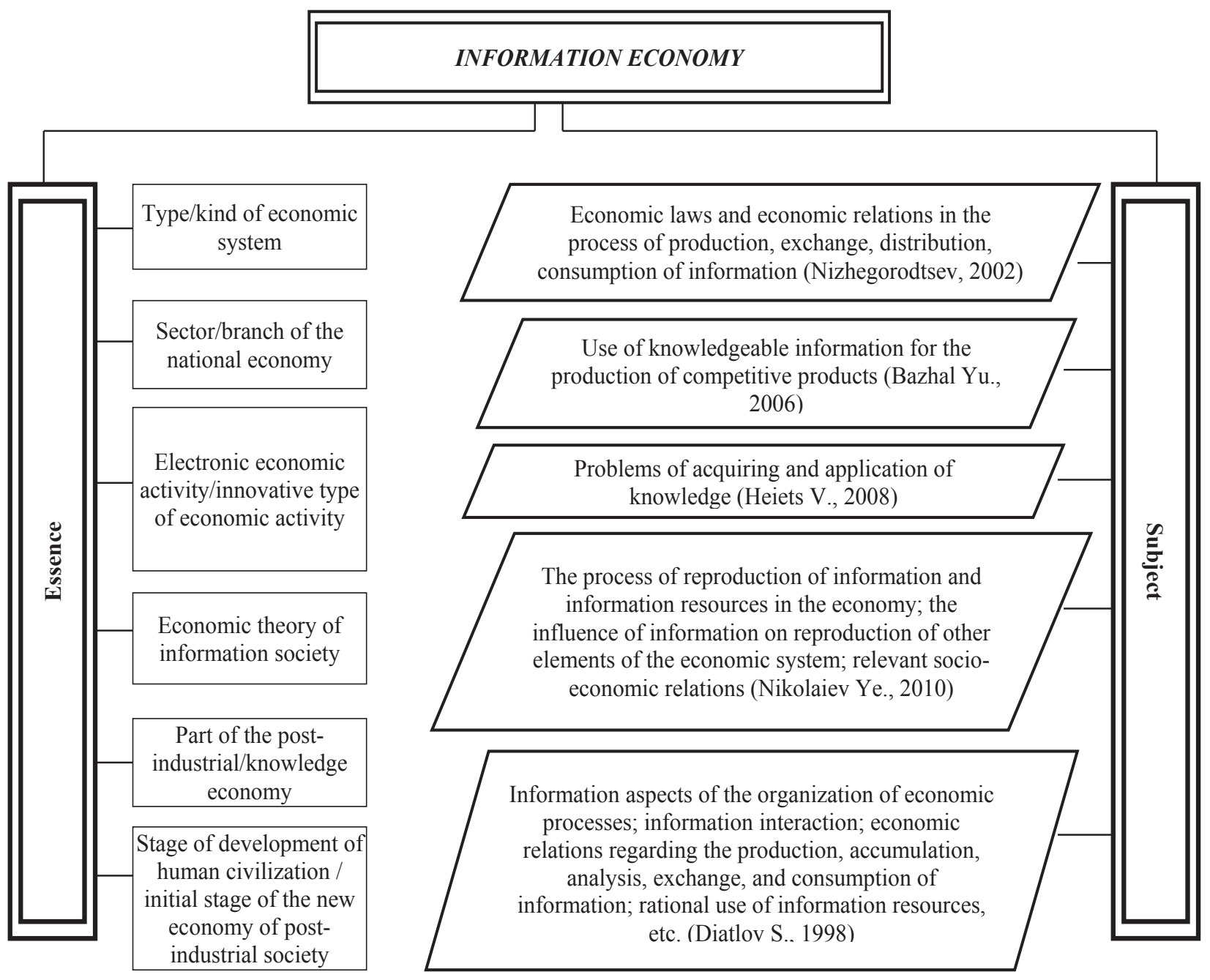

Fig. 1. The main scientific approaches to determining the essence and subject of the information economy 


\section{Conclusions}

Based on the analysis and systematisation of scientific views, we can state that ensuring the competitiveness of economic entities on the micro (local, branch), meso (regional), macro (national), and mega level (international) requires the implementation of flexible and highly adaptive generation mechanisms, accumulation, processing, analysis, transfer of information, effective allocation and use of information resources, prompt updating and introduction of innovative information and communication technologies. In terms of the formation of the information economy, a special significance is held by branches, sectors, and spheres capable of producing knowledge and information, first of all - higher education, science.

Thus, the article analyses the views of domestic and foreign scholars on the essence of the information economy. By systematising the definitions formulated by foreign and Ukrainian scholars, we can note that pluralism is determined by differences in the views of scholars, applied methodology, scientific schools, etc. The analysed definitions are characterized by different levels of concretization, abstraction, scale, complexity, completeness, and systematicity in disclosing the essence of the information economy, including the possibility of identifying the component composition and determinants of its development.

On the basis of systematisation of scientific approaches to the interpretation of this concept, it is proposed to consider the information economy as a type of economic system, which is characterized by the decisive role of information and information technologies in the processes of production, exchange, distribution and consumption, as well as development of major industries and the national economy as a whole.

Prospects for further research are the study, structuring, and systematisation of scientific approaches to the ratio of the categories "information economy" and "knowledge economy" with the specification of key aspects and peculiar features. This will substantially deepen the theoretical and methodological principles of the study of the formation and development processes of the economy of informational type.

\section{References:}

Hrynkevych, S., \& Iliash, O. (2015) Theoretical and Applied Aspects of the Formation of the Information Economy in Ukraine. Strategic Priorities. 2015. № 1 (34). - P. 56-62.

Gubaidullina, D. (2011). Dynamics of the Development of the Information Economy in Russia. 21 p.

Diatlov, S. (1998) The Subject and Method of the Theory of Information Economy. Economic Theory on the 21st Century. - p. 497-519.

Economical dictionary. [Electronic source]. Access mode: http://subject.com.ua/economic/dict/363.html Korneychuk, B. (2006). Information Economy. St. Petersburg, 400 p.

Krystynevych, S. (2008) The Concept of Information Economy: Essence and Development Criteria at the Present Stage. № 3. P. $72-77$.

Maslov, A. (2012). The Theory of Information Economics as an Alternative Paradigm of Modern Orthodoxy. P. 115-119. [Electronic source]. Access mode: http:econom.kiev.ua/paradigm_et/conf_materials.pdf

Melnychuk, O. (2014) The Development of E-commerce in the Structure of the Information Economy of Ukraine. Bulletin of the Taras Shevchenko Kyiv National University. № 8 (161). P. 93-97.

Nizhegorodtsev, R. (2002) Information Economy. Book 1. Information Universe. - Moscow-Kostroma, 163 p.

Nikolaiev, Ye. (2010). The Subject of the Theory of Information Economics. Problems of the formation of a new economy of the XXI century. Dnipropetrovsk. P. 59-61.

Pleskach, V., \& Zatonatska, T. (2007). E-commerce. - Kiyv. 535 p.

Priorities of National Economic Development in the Context of Globalization Challenges (2008). Monograph. (ed. Heiets V., Mazaraki A.). Kiyv. 389 p.

Rakitov, A. (1998). Information, Science, Technology in Global Historical Changes. - Moscow. -104 p.

Tolstyakov, R. (2003). The Main Factors of Information Economy Formation. Tambov. 20 p.

Ukraine in the Measure of Knowledge Economy (2006) (ed. Heiets V.) Kiyv. 592 p.

Financial Dictionary [Electronic source]. Access mode: https://dic.academic.ru/dic.nsf/fin_enc/23440

Chala, O. (2012) Essential Aspects of the Information Economy. Bulletin of the Economy of Transport and Industry. № 40. P. 76-79.

Shkarlet S., \& Dubyna M. Identification of the Essence of the Information Economy. Problems and Prospects of Economy and Management. № 1 (9). P. 99-104.

Cambridge Business English. Dictionary Cambridge University Press. [Electronic source]. Access mode: http:// dictionary.cambridge.org/dictionary/english/information-economy 
Vol. 3, No. 4, 2017

Baltic Journal of Economic Studies

Castells, M. (1996-1998). The Information Age: Economy, Society and Culture. Oxford: Blackwell Publishing. 3 volumes.

Machlup, F. (1962). The Production and Distribution of Knowledge in the United States. NJ.: Princeton. 283 p.

Macmillan Dictionary. [Electronic source]. Access mode: http://www.macmillandictionary.com/dictionary/ british/information-economy

Oxford Dictionary. [Electronic source].Access mode: https://en.oxforddictionaries.com/definition/information_ economy

Porat, Mark U. 1977) The Information Economy. Nine volumes. Office of Telecommunication, US Department of Commerce. Washington, 1977.

\section{Наталия ХОЛЯВКО}

\section{СИСТЕМАТИЗАЦИЯ НАУЧНЫХ ПОДХОДОВ К ТРАКТОВКЕ СУЩНОСТИ ИНФОРМАЦИОННОЙ ЭКОНОМИКИ}

Аннотация. Целью статьи является анализ и систематизация научных подходов к трактовке сущности информационной экономики. Предмет исследования: научные подходы к идентификации сути понятия «информационная экономика». Теоретико-методологическую базу исследования составляют труды Д. Белла, 3. Бжезинского, Ж. Бодияра, М. Кастельса, Э. Масуда, Ф. Махлупа, М. Пората, Э. Тоффлера, посвященные вопросам развития информационного общества. Анализ последних исследований и публикаций позволяет отметить все возрастающий научный интерес кпроблемам становления экономики информационного типа. Сущность и особенности информационной экономики рассматриваются в научных работах ученых Гринкевич С., Иляш А., Кристиневича С., Малик И., Николаева Е., Бажала Ю., Толстякова Г., Шкарлета С., Федуловой Л., Чухно А. т.д. Методы исследования: анализ, контентанализ, синтез, системный метод. Возрастающий научный интерес к проблематике формирования информационной экономики приводит к увеличению количества публикаций по данной тематике; плюрализм научных подходов к рассмотрению сущности информационной экономики актуализирует необходимость их систематизации. Теория информационной экономики логично вытекает и является составной теории развития информационного общества. Наряду с этим, в научной литературе встречается подход, согласно которому ученые отождествляют понятие информационного общества и информационной экономики. По нашему мнению, такой подход недостаточно взвешен, поскольку термин «информационное общество» по своей сути является более широким нежели «информационная экономика». Последний можем рассматривать в качестве неотделимого компонента информационного общества, развитие которого детерминируется рядом специфических факторов. Иными словами, указанные термины тесно взаимосвязаны и их следует исследовать в контексте имеющихся между ними связей, однако не стоит рассматривать как синонимичные понятия. В научной литературе отсутствует единственно согласованное толкование термина «информационная экономика», что объясняется различиями во взглядахиспособахисследования различныхученых. Крометого, этодополняетсявысокой динамичностью экономической составляющей информационного общества, из-за чего постоянно возникают новые аспекты ее изучения. Выводы. В статье проанализированы взгляды отечественных и зарубежных ученых на сущность информационной экономики. Систематизация научных подходов позволила отметить, что их плюрализм определяется различиями во взглядах ученых, используемой методологии, научных школах и пр. Проанализированные дефиниции характеризируются различными степенями конкретности, абстрактности, масштабности, комплексности, полноты и системности в раскрытии сущности информации экономики с возможной идентификацией компонентного состава и детерминантов ее развития. На основе систематизации научных подходов к трактовке данного понятия предложено рассматривать информационную экономику как тип экономической системы, для которой характерна определяющая роль информации и информационных технологий в процессах производства, обмена, распределения и потребления, а также в развитии основных отраслей и национальной экономики в целом. Автор делает акцент на том, что обеспечение конкурентоспособности экономических субъектов на микро- (локальном, отраслевом), макро- (национальном) и мега- (международном) уровнях требует имплементации гибких и высокоадаптивных механизмов генерации, аккумулирования, обработки, 
анализа, трансфера информации, эффективного распределения и использования информационных ресурсов, оперативного обновления и внедрения инновационных информационно-коммуникационных технологий. В условиях формирования информационной экономики особое значение играют отрасли, сектора и сферы, способные к продуцированию знаний и информации, в первую очередь - высшее образование, наука. Перспективы дальнейших исследований заключаются в изучении, структуризации и систематизации научных подходов к соотношению категорий «информационная экономика» и «экономика знаний» с конкретизацией их ключевых особенностей и специфических характеристик. Это позволит существенно углубить теоретико-методологические основы исследования процессов формирования и развития экономики информационного типа. 